\title{
Role of P53 p.Arg72Pro Variant in Recurrent Pregnancy Loss, Recurrent Implantation Failure and IVF Outcome
}

\author{
Navneet Kaur ${ }^{1, ~ *, ~ M o h a m e d ~ E l t o m ~}{ }^{1}$, Karen Cheung ${ }^{1}$, Siddharth Banka ${ }^{2}$, Lamiya Mohiyiddeen ${ }^{1}$ \\ ${ }^{1}$ Department of Reproductive Medicine, Manchester University NHS Foundation Trust, Manchester, United Kingdom \\ ${ }^{2}$ Manchester Centre for Genomic Medicine, Manchester University NHS Foundation Trust, Manchester, United Kingdom
}

Email address:

Navneet.Kaur@mft.nhs.uk (N. Kaur), Mohamed.Eltom@mft.nhs.uk (M. Eltom), Karen.Cheung@mft.nhs.uk (K. Cheung), Siddharth.Banka@mft.nhs.uk (S.Banka), Lamiya.Mohiyiddeen@mft.nhs.uk (L. Mohiyiddeen)

${ }^{*}$ Corresponding author

\section{To cite this article:}

Navneet Kaur, Mohamed Eltom, Karen Cheung, Siddharth Banka, Lamiya Mohiyiddeen. Role of P53 p.Arg72Pro Variant in Recurrent Pregnancy Loss, Recurrent Implantation Failure and IVF Outcome. International Journal of Genetics and Genomics.

Vol. 8, No. 3, 2020, pp. 94-101. doi: 10.11648/j.ijgg.20200803.11

Received: June 17, 2020; Accepted: July 27, 2020; Published: September 8, 2020

\begin{abstract}
The role of $p 53$ p.Arg72Pro variant in recurrent pregnancy loss, recurrent implantation failure and IVF outcome is controversial and research so far has yielded inconsistent results. This systematic review aims to summarise the literature on the role of TP53 p.Arg72Pro variant in recurrent pregnancy loss following natural and assisted conception. A comprehensive literature search was conducted on MEDLINE, EMBASE and CENTRAL electronic databases for literature published between 1998 and April 2020. Inclusion and exclusion criteria and search terms were established. References of retrieved articles were hand searched to identify other relevant papers including conference abstracts. In total, 9 case control studies (1041 patients), 6 case control studies (382 patients) and 7 studies (3403) were included examining the role of TP53 p.Arg72Pro variant in recurrent pregnancy loss, recurrent implantation failure and IVF outcome respectively. Combined genotype frequencies suggest that there may be an association between Pro/Pro genotype and recurrent pregnancy loss and Arg/Pro genotype and recurrent implantation failure. However, the association between TP53 p.Arg72Pro variant and recurrent pregnancy loss, recurrent implantation failure or IVF outcomes has not been clearly established. In conclusion, genotyping patients for the TP53 variant may enable us to identify an aetiology for patients experiencing unexplained recurrent pregnancy loss and detect individuals at risk of recurrent implantation failure before IVF treatment is initiated. Furthermore, exploring the mechanisms of action of the p53 protein may provide us with an insight into potential treatments.
\end{abstract}

Keywords: P53, Gene Polymorphism, Gene Variant, Recurrent Miscarriage, Recurrent Implantation Failure, IVF

\section{Introduction}

The European Society of Human Reproduction and Embryology (ESHRE) and the American Society of Human Reproductive Medicine (ASRM) define recurrent pregnancy loss (RPL) as two or more consecutive proven pregnancy losses before 20 weeks of gestation [1]. RPL occurs in about $1 \%$ of pregnancies [2]. Recurrent implantation failure (RIF) is defined as repetitive failure to achieve a clinical pregnancy after the transfer of good quality embryos in three or more cycles of IVF treatment [3-4]. Although the pathophysiology is not fully understood, RPL is probably a disorder at the level of implantation, affecting apposition (or adplantation), adhesion or embryo invasion through the stroma of the endometrium [3], which would explain why the vast majority of miscarriages occur in the early stages of pregnancy.

RPL is a complex heterogenous disorder, the underlying pathophysiology involves many possible factors. Maternal age, endometrial pathology, infectious, endocrinological, immunological, prothrombotic disorders as well as environmental factors have all been implicated [3, 5-7]. Despite these potentially identifiable aetiological causes, up to $50 \%$ of cases of RPL remain idiopathic [3, 5-7]. Due to the fact that most pregnancy loss occurs during the implantation or early embryonic stages of development, it has been suggested that any factor which alters the intricate balance 
between proliferation, angiogenesis and apoptosis may interfere with implantation or early embryonic development [8]. This intricate balance between combinations of essential mediators contributes to the success of trophoblast invasion and placental differentiation which is essential for the growth and development of the growing fetus. A disturbance of this balance may impair the chances of a successful pregnancy.

Genetic variants, may influence the balance of these mediators, thus reducing the chances of a successful pregnancy. Few clinically significant relationships between variants and RPL/RIF have been established [8-11].

TP53 is a tumour-suppressor gene that encodes p53, a transcription factor implicated in a number of cellular processes It has a clearly established role in the regulation of apoptosis, angiogenesis and repair of DNA damage [12]. Numerous post-translational modifications regulate $\mathrm{p} 53$ activity. Mutation of the gene itself or loss of cell signaling upstream or downstream can cause loss of activity of p53 [12]. Research has also suggested that $\mathrm{p} 53$ could be a potential pregnancy mediator, and thus genetic variations of TP53 could be a potential risk factor for idiopathic RPL and RIF [11-13].

The growing interest in TP53 variants and RPL/RIF has drawn researchers' attention to be focused on rs1042522 polymorphism variant [chr 17: 7676154 (GRCh38.p12); N M_000546.6: c.215C $>$ T; NP_000537.3: p.Arg72Pro], [14-15]. Studies have suggested that TP53 p.Arg72Pro variants induce lower apoptotic activity and higher levels of G1 cell cycle arrest compared to wildtype variants [16]. This leads to inadequate trophoblastic invasion and subsequently increases the risk of RPL and RIF [17].

The primary objective of this study is to conduct a systematic review of the literature investigating the role of TP53 p.Arg72Pro variant in recurrent pregnancy loss, recurrent implantation failure and IVF outcome.

\section{Methods}

A search of three electronic databases - MEDLINE, EMBASE and CENTRAL- targeting reports published between 1998 and April 2020 was conducted. The search strategy used the terms 'p53', 'p53 codon polymorphism', 'p.Arg72Pro', 'rs1042522', 'recurrent pregnancy loss', 'recurrent implantation failure', 'recurrent spontaneous abortion' and 'IVF'. The references of retrieved articles were hand searched to identify other relevant papers including conference abstracts. Studies that investigated the effects of TP53 p.Arg72Pro (rs1042522) on recurrent implantation failure recurrent pregnancy loss and IVF were included. Criteria for inclusion and exclusion of studies were established prior to the literature search. The main outcomes sought were the relationship between TP53 p.Arg72Pro and recurrent implantation failure, recurrent pregnancy loss and IVF outcomes (See Appendix: Figure 1 - PRISMA Flow Diagram).

\section{Results}

Nine studies that examined the role of the $p 53$ p.Arg72Pro variant and RPL [18-26] and six studies that examined the role of this variant and RIF were retrieved [18, 20, 27-30]. The type of study, subjects included, frequency of the genotypes in the study groups and control groups are outlined in Appendix: Tables 1 and 2. Seven studies examining the role of $p 53$ p.Arg72Pro variant and IVF outcomes were retrieved [14, 30-35]. The results of these studies are outlined in Appendix: Table 3.

Three studies (Firouzibadi et al., 2009, Pietrowski et al., 2004 and Lledo et al., 2013) [18-20] report an association between the single nucleotide polymorphism and RPL. Firouzibadi et al., 2009 report a significant difference in genotype homozygous Pro/Pro in RPL and significant differences in Pro allele frequency in the RPL group compared to the other groups (Chi-squared value 0.002) [18]. Pietrowski et al., 2004 report a statistically significant association between carriage of Pro allele and idiopathic RPL $(\mathrm{p}=0.03)$ [19]. Lledo et $a l ., 2013$ report that in RPL the frequency of Pro/Pro genotypes on the $p 53$ gene among women experiencing RPL was $18.5 \%$ compared to $6 \%$ in the control group $(\mathrm{p}<0.01)$ [20]. In contrast to this, 6 studies (Yoon et al., 2015, Fraga et al., 2014, Kaare et al., 2009, Coulam et al., 2006, Oliveira et al., 2013 and Franco Jr et al., 2013) report no association between the p53 p.Arg72Pro variant and RPL [21-26].

Combining the genotype frequency study data, $48 \%$ (498/1041) RPL patients were Arg/Arg compared to 50\% (514/1029) controls. 39\% (410/1041) RPL patients were Arg/Pro compared to $42 \% \quad(433 / 1029)$ controls. $13 \%$ (133/1041) RPL patients were Pro/Pro compared to only $8 \%$ $(82 / 1029)$ controls.

Three studies (Kay et al., 2006, Lledo et al., 2013, Firouzibadi et al., 2009) report an association between $p 53$ p.Arg72Pro variant and RIF [27, 20, 18]. Kay et al., 2006 report a significantly higher frequency of Pro72 $(\mathrm{p}=0.003)$ among women experiencing RIF compared with women experiencing RPL and the control group [27]. Lledo et al., 2013 reported that the frequency of Pro/Pro genotypes on the p53 gene among women experiencing RIF was $11.4 \%$ vs $6 \%$ in the control group $(\mathrm{p}<0.01)$ [20]. However, Firouzibadi et al., 2009 report that the Arg allele frequency was significantly higher in the RIF patients than the control and RPL groups with an allelic value of 0.002 [18]. Three studies (Goodman et al., 2009, Vagnini et al., 2013, Allanfan et al., 2015) found no association between $p 53$ p.Arg72Pro variant and RIF [28-30].

Combining the genotype frequency data, $47 \%$ of patients with RIF (146/312) were Arg/Arg compared to $60 \%$ of controls (138/230). 44\% (138/312) of patients with RIF were Arg/Pro compared to $33 \%$ of controls (75/230) and $9 \%$ (34/382) of patients with RIF were Pro/Pro compared to $7 \%$ $(19 / 303)$ controls.

Seven studies (Paskulin et al., 2012, Kang et al., 2009, Patounakis et al., 2008, Ghorbian et al., 2019, Chan et al., 2016, Baruffi et al., 2014, Allanfan et al., 2015) reviewed the association between $p 53$ p.Arg72Pro variant and IVF outcome [14, 30-35]. Three studies (Paskulin et al., 2012, Kang et al., 2009, Chan et al., 2016) found an association between $p 53$ p.Arg72Pro variant and IVF outcome [31, 14, 34]. Paskulin et al., 2012 report an association between p.Arg72Pro and IVF 
$(\mathrm{p}=0.009)$ when comparing with selected and unselected controls [31]. Kang et al., 2009 found a significantly lower implantation rate in patients homozygous Pro/Pro (19\%) compared with patients carrying at least 1 allele of Arg (42\%) $\mathrm{p}=0.0028$, which resulted in a lower clinical pregnancy rate for patients homozygous for Pro/Pro in patients less than 35 years old [14]. In older patients there was no significant difference in implantation and pregnancy rates [14]. In contrast, Chan et al., 2016 reported the $\mathrm{C}$ allele (Pro) showed a higher frequency in the clinical pregnancy group $(\mathrm{p}=0.01)$ and an association was found between the $\mathrm{C}$ allele (Pro) and IVF outcome $(\mathrm{OR}=0.83$, $95 \%$ CI: $0.71+/-0.96, p=0.01)$, suggesting that the Pro allele decreased the risk of pregnancy failure after IVF [34].

\section{Discussion}

As demonstrated the complex relationship between $p 53$ p.Arg72Pro variant and RPL and RIF is far from being understood. This systematic review suggests that the frequency of Pro/Pro genotype carriers compared to genotypes Arg/Pro and Arg/Arg may be higher in the RPL population compared to the control group, and the frequency of Arg/Pro genotype carriers compared to Arg/Arg and Pro/Pro may be higher in the recurrent implantation failure population compared to the control group, suggesting that this area requires further investigation.

These results are consistent with five meta-analyses examining the relationship between $p 53$ p.Arg72Pro variant and RPL [11, 36-39]. Tang et al., 2011 analyzed four case control studies and concluded that women with the homozygous Pro/Pro genotype had an increased risk of RPL [11]. Su et al., 2011 analysed four case control studies and showed that women who carried the TP53 p.Arg72Pro variant had a higher risk of RPL in the recessive model [36]. Chen et al., 2015 analysed six case control studies and suggested that a Pro/Pro genotype in an additive model and recessive model were associated with an increased risk of RPL compared to genotypes Arg/Arg and Arg/Pro [37]. Zhang et al., 2016 analysed six case control studies and concluded that there is a significant association between TP53 p.Arg72Pro and RPL in the Pro/Pro co-dominant and recessive models compared to women with genotypes Arg/Pro and Arg/Arg [38]. Shi et al., 2017 reviewed 6 case control studies and found a significant association between recurrent pregnancy loss and TP53 p.Arg72Pro variant [39]. However, this concordance is unsurprising as all the papers analysed similar papers due to the paucity of literature available. In contrast to this, a meta-analysis by Wiwanitkit et al., 2011 concluded that there was no correlation between p53 p.Arg72Pro variant and RPL, however this meta-analysis only looked at 2 case reports, both of which were included in the larger meta-analyses discussed above [40].

The relationship between $p 53$ p.Arg72Pro variant and RIF or IVF outcome is less clear. There are two meta-analyses examining the relationship between RIF and p53 p.Arg72Pro variant. Feng et al., 2016 found there was no significant association between RIF amongst patients with Pro/Pro genotype or Arg/Pro genotype compared to Arg/Arg [41], and similarly, Wiwanitkit et al., 2011 found there was no correlation between RIF and p53 variant [40]. Our study combining the genotype frequency data suggests that the frequency of Arg/Pro genotype carriers compared to Arg/Arg and Pro/Pro may be higher in the recurrent implantation failure population compared to the control group, which has not been shown in the previous meta-analyses. Furthermore, the studies included that examined TP53 p.Arg72Pro and IVF outcome were contrasting, with 2 studies reporting a worse outcome with carrying the Pro allele $[14,31]$ compared to 1 study reporting a better outcome with carrying the Pro allele [34], highlighting the need for further research to examine the role of p53 p. Arg72Pro variant in RIF and IVF outcome.

Successful trophoblast invasion and embryonic development is regulated by a careful balance between mediators involved in proliferation and apoptosis. [17, 38, 42-43]. The $\mathrm{p} 53$ protein has an important role in regulating the cell cycle, apoptosis and protecting the genome [36] and is necessary for successful invasion of trophoblast cells [38]. P53 variant changes the functional activity of p53, $(17,43)$. The $\mathrm{C}$ allele variant causes Arg to be replaced by Pro. The Arg72 variant is better than the Pro72 variant at inducing apoptosis and suppressing cellular transformation [11], the Pro72 variant induces a higher level of G1 cell cycle arrest than the Arg72 variant and induces a lower level of apoptotic activity $[11,38]$. This may result in inadequate trophoblastic invasion and therefore lead to an increased risk of RPL or RIF in Pro carriers. Furthermore, the p53 protein is involved in the regulation of leukaemia inhibitory factor (LIF), an important cytokine that influences the receptivity of the endometrium and implantation of the blastocyst [11]. Arg72 has been shown to be more active than Pro72 in activating LIF and therefore Pro carriers may have an increased risk of RPL or RIF through altered p53 activity and reduced LIF [11].

Although we have included a comprehensive systematic overview of the literature and combined genotype frequency results, there are differences in the inclusion and exclusion criteria of the patient groups recruited into the studies, which does not allow statistical combination of the results. In the RPL group, some studies recruited patients with 2 consecutive pregnancy losses [18, 20-22, 24-26], however other studies included only 3 or more consecutive pregnancy losses [19, 23]. Furthermore the gestation limit of the previous miscarriages, method of diagnosis of previous miscarriage, pregnancy history and the diagnostic tests performed prior to confirmation of idiopathic RPL varied significantly between the studies. Similarly, in the RIF group some studies recruited patients with 2 consecutive IVF cycle failures [18, 27, 30] or IVF failure after 4 cleaved good quality embryos [20, 29] or IVF failure after 8 cleaved embryos or 4 blastocysts [28]. Similarly, the control groups between the studies are dissimilar for example two studies recruited postmenopausal women $[19,21]$ with the remainder recruiting premenopausal women. This heterogeneity between the studies suggests that results should be considered with caution.

Literature has shown that the allele frequencies of $p 53$ variant vary according to populations with different ethnic backgrounds. It seems that the Pro allele is the ancestral allele 
and it has around a $60 \%$ frequency in African populations compared to around $25-35 \%$ frequency in Caucasian and Asian populations [45]. The case control studies have been conducted in various countries including South Korea [21], Brazil [22, 25-26, 29, 31, 35], Iran (18, 30, 33), Finland [23], Austria [19], USA [24, 28, 27, 14, 32], Spain [20] and China [34] and therefore they include a wide range of ethnicities. Furthermore, it is likely that different $p 53$ genotypes in different populations may be associated with different risks of RPL/RIF. However despite this association, a firm conclusion cannot be reached on the impact of $p 53$ variant in different populations, as it is difficult to account for environmental confounding factors that may exist in particular ethnic groups and subsequently influence the pregnancy outcome. This highlights the importance of stratification of the results according to ethnicity, which was not performed in all the research studies and also reflects the need for well-matched control groups in any future studies.

Advancing maternal age is associated with reduced oocyte quality, which may contribute to recurrent implantation failure, and therefore we would expect that RIF may be a more significant cause for subfertility in younger patients with unexplained subfertility compared to older patients. Literature suggests that the association of p53 variants with reduced fertility mainly occurs in younger patients and the association is reduced with advancing maternal age, suggesting that it may also be important to consider stratification according to maternal age in any future research [43].

The p53 pathway is complex network with negative and positive regulators of $\mathrm{p} 53$, for example MDM 2, MDM4 and Hausp [44]. Each of these regulators also have genetic variants which can further effect the p53 pathway and could impact implantation and other aspects of fertility [44]. This highlights the complexity in investigating the role of p53 variant in RIF/RPL, it may be that in future research studies, patients and control groups are investigated for a number of variants simultaneously to enable us to further understand this pathway and its' association with RPL, RIF and IVF outcome.

\section{Conclusion}

This systematic review has demonstrated that the frequency of Pro/Pro genotype carriers may be higher in the RPL population and the frequency of Arg/Pro genotype carriers may be higher in the RIF population. Genotyping patients for the TP53 variant may enable us to identify an aetiology for patients experiencing unexplained RPL and also detect individuals at risk of RIF before IVF treatment is initiated. Furthermore, exploring the mechanisms of action of the p53 protein will provide us with an insight into potential treatments of RPL and RIF.

\section{Appendix}

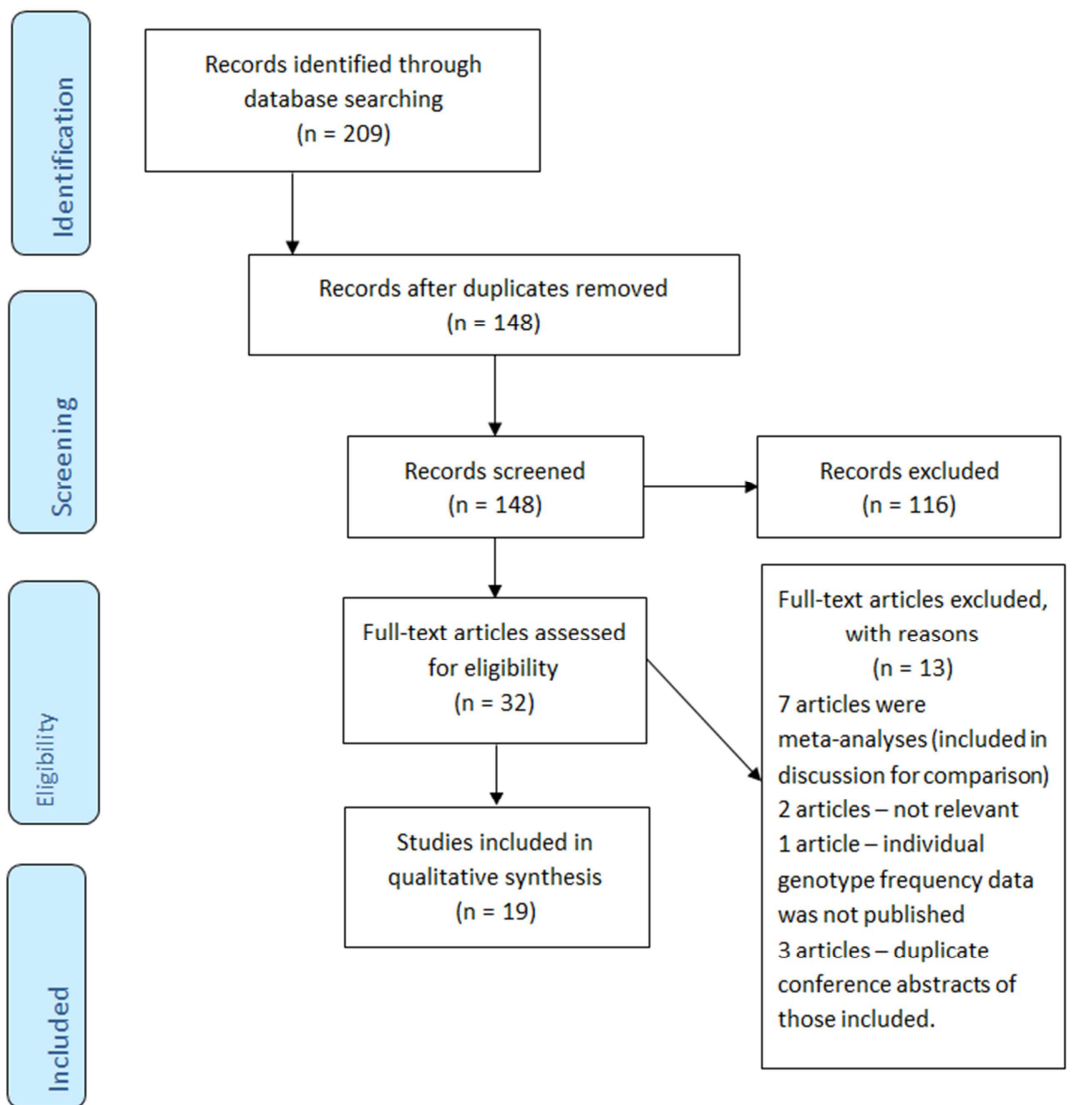

Figure 1. PRISMA Flow Diagram. 
Table 1. Details of Studies Included in the Review: Recurrent Pregnancy Loss.

\begin{tabular}{|c|c|c|c|c|c|c|}
\hline \multirow{2}{*}{ Authors } & \multirow{2}{*}{ Subjects } & \multirow{2}{*}{ Location } & \multicolumn{3}{|c|}{ Genotype frequencies } & \multirow{2}{*}{ Conclusion } \\
\hline & & & Arg/Arg (\%) & Arg/Pro (\%) & Pro/Pro (\%) & \\
\hline $\begin{array}{l}\text { Yoon et al., } \\
2015\end{array}$ & $\begin{array}{l}\text { Study: } 294 \text { women with } \\
\text { RPL Control: } 300 \\
\text { postmenopausal } \\
\text { women }\end{array}$ & South Korea & $\begin{array}{l}\text { RPL: } 42.9 \% \\
(126 / 294) \\
\text { Control: } 39.3 \% \\
(118 / 300)\end{array}$ & $\begin{array}{l}\text { RPL: } 44.9 \% \\
\text { (132/294) } \\
\text { Control: } 51 \% \\
(153 / 300)\end{array}$ & $\begin{array}{l}\text { RPL: } 12.2 \% \\
\text { (36/294) } \\
\text { Control: } 9.7 \% \\
(29 / 300)\end{array}$ & $\begin{array}{l}\text { No significant differences in } \\
\text { the genotype distributions or } \\
\text { allele frequencies }\end{array}$ \\
\hline $\begin{array}{l}\text { Fraga et al., } \\
2014\end{array}$ & $\begin{array}{l}\text { Study: } 120 \text { women with } \\
\text { RPL Control: } 143 \\
\text { fertile women }\end{array}$ & $\begin{array}{l}\text { Southern } \\
\text { Brazil }\end{array}$ & $\begin{array}{l}\text { RPL: } 47.5 \% \\
(57 / 120) \\
\text { Control: } 50.3 \% \\
(72 / 143)\end{array}$ & $\begin{array}{l}\text { RPL: } 39.2 \% \\
(47 / 120) \\
\text { Control: } 42 \% \\
(60 / 143)\end{array}$ & $\begin{array}{l}\text { RPL: } 13.3 \% \\
\text { (16/120) } \\
\text { Control: } 7.7 \% \\
(11 / 143)\end{array}$ & $\begin{array}{l}\text { No significant difference in } \\
\text { the genotype distributions or } \\
\text { allele frequencies }\end{array}$ \\
\hline $\begin{array}{l}\text { Firouzabadi } \\
\text { et al., } 2009\end{array}$ & $\begin{array}{l}\text { Study: } 97 \text { women with } \\
\text { RPL Control: } 32 \\
\text { premenopausal women }\end{array}$ & Iran & $\begin{array}{l}\text { RPL: } 23.7 \% \\
\text { (23/97) } \\
\text { Control: } 12.5 \% \\
(4 / 32)\end{array}$ & $\begin{array}{l}\text { RPL: } 42.3 \% \\
\text { (41/97) } \\
\text { Control: } 65.6 \% \\
(21 / 32)\end{array}$ & $\begin{array}{l}\text { RPL: } 34 \%(33 / 97) \\
\text { Control: } 21.9 \% \\
(7 / 32)\end{array}$ & $\begin{array}{l}\text { Significant difference in } \\
\text { women homozygous Pro/Pro } \\
\text { and in Pro allele freqency in } \\
\text { RPL compared to the other } \\
\text { groups }\end{array}$ \\
\hline $\begin{array}{l}\text { Kaare et al., } \\
2009\end{array}$ & $\begin{array}{l}\text { Study: } 46 \text { women with } \\
\text { RPL Control: } 191 \\
\text { women }\end{array}$ & Finland & $\begin{array}{l}\text { RPL: } 45.6 \% \\
(21 / 46) \\
\text { Control: } 55.5 \% \\
(106 / 191)\end{array}$ & $\begin{array}{l}\text { RPL: } 47.8 \% \\
\text { (22/46) } \\
\text { Control: } 40.3 \% \\
\text { (77/191) }\end{array}$ & $\begin{array}{l}\text { RPL: } 6.5 \%(3 / 46) \\
\text { Control: } 4.2 \% \\
(8 / 191)\end{array}$ & $\begin{array}{l}\text { No significant difference in } \\
\text { the genotype distributions or } \\
\text { allele frequency }\end{array}$ \\
\hline $\begin{array}{l}\text { Pietrowski et } \\
\text { al., } 2004\end{array}$ & $\begin{array}{l}\text { Study: } 175 \text { women with } \\
\text { RPL Control: } 143 \\
\text { postmenopausal } \\
\text { women }\end{array}$ & Austria & $\begin{array}{l}\text { RPL: } 47.4 \% \\
\text { (83/175) } \\
\text { Control: } 58 \% \\
(83 / 143)\end{array}$ & $\begin{array}{l}\text { RPL: } 40 \% \\
\text { (70/175) } \\
\text { Control: } 35 \% \\
(50 / 143)\end{array}$ & $\begin{array}{l}\text { RPL: } 12.6 \% \\
\text { (22/175) } \\
\text { Control: } \\
7 \% \\
(10 / 143)\end{array}$ & $\begin{array}{l}\text { Statistically significant } \\
\text { association between carriage } \\
\text { of Pro allele and RPL }\end{array}$ \\
\hline $\begin{array}{l}\text { Coulam et al., } \\
2006\end{array}$ & $\begin{array}{l}\text { Study: } 205 \text { women with } \\
\text { RPL Control: } 21 \\
\text { premenopausal women } \\
\text { with } 2+\text { livebirths }\end{array}$ & USA & $\begin{array}{l}\text { RPL: } 68.8 \% \\
(141 / 205) \\
\text { Control: } 61.9 \% \\
(13 / 21)\end{array}$ & $\begin{array}{l}\text { RPL: } 26.8 \% \\
(55 / 205) \\
\text { Control: } 38.1 \% \\
(8 / 21)\end{array}$ & $\begin{array}{l}\text { RPL: } 4.4 \%(9 / 205) \\
\text { Control: } \\
0 \%\end{array}$ & $\begin{array}{l}\text { No significant difference in } \\
\text { the genotype or allele } \\
\text { frequencies }\end{array}$ \\
\hline $\begin{array}{l}\text { Lledo et al., } \\
2013\end{array}$ & $\begin{array}{l}\text { Study: } 54 \text { women with } \\
\text { RPL } \\
\text { Control: } 83 \text { oocyte } \\
\text { donors }\end{array}$ & Spain & $\begin{array}{l}\text { RPL: } 51.9 \% \\
(28 / 54) \\
\text { Control: } 65.1 \% \\
(54 / 83)\end{array}$ & $\begin{array}{l}\text { RPL: } 29.6 \% \\
(16 / 54) \\
\text { Control: } 28.9 \% \\
(24 / 83)\end{array}$ & $\begin{array}{l}\text { RPL: } 18.5 \%(10 / 54) \\
\text { Control: } \\
6 \% \\
(5 / 83)\end{array}$ & $\begin{array}{l}\text { In RIF and RPL patients R72P } \\
\text { on } p 53 \text { gene is more prevalent }\end{array}$ \\
\hline $\begin{array}{l}\text { Oliveira et } \\
\text { al., } 2013\end{array}$ & $\begin{array}{l}\text { Study: } 23 \text { couples with } \\
\text { RPL Control: } 55 \\
\text { couples with } 2 \\
\text { livebirths }\end{array}$ & Brazil & $\begin{array}{l}\text { RPL: } 39.1 \% \\
(9 / 23) \\
\text { Control: } 54.5 \% \\
(30 / 55)\end{array}$ & $\begin{array}{l}\text { RPL: } 56.5 \% \\
(13 / 23) \\
\text { Control: } 34.6 \% \\
(19 / 55)\end{array}$ & $\begin{array}{l}\text { RPL: } 4.4 \%(1 / 23) \\
\text { Control: } 10.9 \% \\
(6 / 55)\end{array}$ & $\begin{array}{l}\text { No significant difference in } \\
\text { genotype or allele frequencies }\end{array}$ \\
\hline $\begin{array}{l}\text { Franco } \mathrm{Jr} \text { et } \\
\text { at., } 2013\end{array}$ & $\begin{array}{l}\text { Study: } 27 \text { women with } \\
\text { RPL } \\
\text { Control: } 61 \text { women } \\
\text { with } 2 \text { livebirths }\end{array}$ & Brazil & $\begin{array}{l}\text { RPL: } 37 \% \\
(10 / 27) \\
\text { Control: } 55.7 \% \\
(34 / 61)\end{array}$ & $\begin{array}{l}\text { RPL: } 51.9 \% \\
(14 / 27) \\
\text { Control: } 34.5 \% \\
(21 / 61)\end{array}$ & $\begin{array}{l}\text { RPL: } 11.1 \%(3 / 27) \\
\text { Control: } 9.8 \% \\
(6 / 61)\end{array}$ & $\begin{array}{l}\text { No significant difference in } \\
\text { genotype or allele frequency }\end{array}$ \\
\hline & & TOTAL & $\begin{array}{l}\text { RPL: } 48 \% \\
(498 / 1041) \\
\text { Control: } 50 \% \\
(514 / 1029)\end{array}$ & $\begin{array}{l}\text { RPL: } 39 \% \\
(410 / 1041) \\
\text { Control: } 42 \% \\
(433 / 1029)\end{array}$ & $\begin{array}{l}\text { RPL: } 13 \% \\
\text { (133/1041) Control: } \\
8 \%(82 / 1029)\end{array}$ & \\
\hline
\end{tabular}

Table 2. Details of Studies Included in the Review: Recurrent Implantation Failure.

\begin{tabular}{|c|c|c|c|c|c|c|}
\hline \multirow{2}{*}{ Author } & \multirow{2}{*}{ Subjects } & \multirow{2}{*}{ Location } & \multicolumn{3}{|c|}{ Genotype Frequencies } & \multirow{2}{*}{ Conclusion } \\
\hline & & & $\operatorname{Arg} / \operatorname{Arg}(\%)$ & Arg/Pro (\%) & Pro/Pro (\%) & \\
\hline $\begin{array}{l}\text { Firouzabadi et } \\
\text { al., } 2009\end{array}$ & $\begin{array}{l}\text { Study: } 70 \text { women with RIF } \\
\text { Control: } 32 \text { premenopausal } \\
\text { women }\end{array}$ & Iran & $\begin{array}{l}\text { RIF: } 42.9 \% \\
(30 / 70) \\
\text { Control: } \\
12.5 \%(4 / 32)\end{array}$ & $\begin{array}{l}\text { RIF: } 40 \%(28 / 70) \\
\text { Control: } 65.6 \% \\
(21 / 32)\end{array}$ & $\begin{array}{l}\text { RIF: } 17.1 \% \\
(12 / 70) \\
\text { Control: } 21.9 \% \\
(7 / 32)\end{array}$ & $\begin{array}{l}\text { Arg allele frequency was } \\
\text { significantly higher in the } \\
\text { RIF patients than in the } \\
\text { control and RPL groups }\end{array}$ \\
\hline $\begin{array}{l}\text { Goodman et al., } \\
2009\end{array}$ & $\begin{array}{l}\text { Study: } 70 \text { women with RIF } \\
\text { Control: } 73 \text { fertile women }\end{array}$ & USA & $\begin{array}{l}\text { Data not } \\
\text { available }\end{array}$ & $\begin{array}{l}\text { Data not } \\
\text { available }\end{array}$ & $\begin{array}{l}\text { RIF: } 9 \%(6 / 70) \\
\text { Control: } \\
1 \%(1 / 73)\end{array}$ & $\begin{array}{l}\text { No significant difference in } \\
\text { genotype or allele frequencies }\end{array}$ \\
\hline Kay et al., 2006 & $\begin{array}{l}\text { Study: } 70 \text { women with RIF } \\
\text { Control: } 20 \text { fertile women }\end{array}$ & USA & $\begin{array}{l}\text { RIF: } 47 \% \\
(33 / 70) \\
\text { Control: } 62 \% \\
(13 / 20)\end{array}$ & $\begin{array}{l}\text { RIF: } 46 \%(32 / 70) \\
\text { Control: } 38 \% \\
(8 / 20)\end{array}$ & $\begin{array}{l}\text { RIF: } 7 \%(5 / 70) \\
\text { Control: } 0 \%\end{array}$ & $\begin{array}{l}\text { The frequency of Pro } 72 \text { was } \\
\text { significantly higher in RIF }\end{array}$ \\
\hline $\begin{array}{l}\text { Lledo et al., } \\
2013\end{array}$ & $\begin{array}{l}\text { Study: } 44 \text { women with RIF } \\
\text { Control: } 83 \text { oocyte donors }\end{array}$ & Spain & $\begin{array}{l}\text { RIF: } 40.9 \% \\
(18 / 44) \\
\text { Control: } \\
65.1 \%(54 / 83)\end{array}$ & $\begin{array}{l}\text { RIF: } 47.7 \% \\
\text { (21/44) } \\
\text { Control: } 28.9 \% \\
(24 / 83)\end{array}$ & $\begin{array}{l}\text { RIF: } 11.4 \%(5 / 44) \\
\text { Control: } \\
6 \%(5 / 83)\end{array}$ & $\begin{array}{l}\text { In RIF patients } \mathrm{R} 72 \mathrm{P} \text { on } p 53 \\
\text { gene is more prevalent }\end{array}$ \\
\hline $\begin{array}{l}\text { Vagnini et al., } \\
2013\end{array}$ & $\begin{array}{l}\text { Study: } 108 \text { couples with RIF } \\
\text { Control: } 55 \text { couples with } 2\end{array}$ & Brazil & $\begin{array}{l}\text { RIF: } 45.5 \% \\
(49 / 108)\end{array}$ & $\begin{array}{l}\text { RIF: } 49.1 \% \\
(53 / 108)\end{array}$ & $\begin{array}{l}\text { RIF: } 5.5 \%(6 / 108) \\
\text { Control: } 10.9 \%\end{array}$ & $\begin{array}{l}\text { No significant difference in } \\
\text { genotype or allele frequencies }\end{array}$ \\
\hline
\end{tabular}




\begin{tabular}{|c|c|c|c|c|c|c|}
\hline \multirow{2}{*}{ Author } & \multirow{2}{*}{ Subjects } & \multirow{2}{*}{ Location } & \multicolumn{3}{|c|}{ Genotype Frequencies } & \multirow{2}{*}{ Conclusion } \\
\hline & & & $\operatorname{Arg} / \operatorname{Arg}(\%)$ & Arg/Pro (\%) & Pro/Pro (\%) & \\
\hline \multirow{3}{*}{$\begin{array}{l}\text { Allanfan et al., } \\
2015\end{array}$} & livebirths & & $\begin{array}{l}\text { Control: } \\
54.5 \%(30 / 55)\end{array}$ & $\begin{array}{l}\text { Control: } 34.6 \% \\
(19 / 55)\end{array}$ & $(6 / 55)$ & \multirow{3}{*}{$\begin{array}{l}\text { No significant difference in } \\
\text { genotype or allele frequencies }\end{array}$} \\
\hline & $\begin{array}{l}\text { Study: Group 2: } 20 \text { women } \\
\text { with RIF } \\
\text { Control: } 40 \text { women } \\
\text { successfully pregnant after } \\
\text { IVF }\end{array}$ & Iran & $\begin{array}{l}\text { RIF: } 80 \% \\
\text { (16/20) } \\
\text { Control: } \\
92.5 \%(37 / 40)\end{array}$ & $\begin{array}{l}\text { RIF: } 20 \%(4 / 20) \\
\text { Control: } 7.5 \% \\
(3 / 40)\end{array}$ & none & \\
\hline & & TOTAL & $\begin{array}{l}\text { RIF: } 47 \% \\
(146 / 312) \\
\text { Control: } 60 \% \\
(138 / 230)\end{array}$ & $\begin{array}{l}\text { RIF: } 44 \% \\
\text { (138/312) } \\
\text { Control: } 33 \% \\
(75 / 230)\end{array}$ & $\begin{array}{l}\text { RIF: } 9 \%(34 / 382) \\
\text { Control: } \\
7 \%(19 / 303)\end{array}$ & \\
\hline
\end{tabular}

Table 3. Details of Studies Included in the Review: IVF Outcome.

\begin{tabular}{|c|c|c|c|c|c|c|}
\hline \multirow{2}{*}{ Author } & \multirow{2}{*}{ Subjects } & \multirow{2}{*}{ Location } & \multicolumn{3}{|l|}{ Genotype Frequencies } & \multirow{2}{*}{ Conclusion } \\
\hline & & & Arg/Arg (\%) & Arg/Pro (\%) & Pro/Pro (\%) & \\
\hline $\begin{array}{l}\text { Paskulin et } \\
\text { al., } 2012\end{array}$ & $\begin{array}{l}\text { Study: } 115 \text { women post } \\
\text { IVF failure } \\
\text { Control: } 134 \text { fertile women }\end{array}$ & Brazil & $\begin{array}{l}\text { IVF: } 54.8 \%(63 / 115) \\
\text { Control: } \\
66.4 \% \\
(89 / 134)\end{array}$ & $\begin{array}{l}\text { IVF: } 30.4 \%(35 / 115) \\
\text { Control: } \\
29.9 \% \\
(40 / 115)\end{array}$ & $\begin{array}{l}\text { IVF: } 14.8 \% \\
(17 / 11 \%) \\
\text { Control: } \\
3.7 \% \\
(5 / 134)\end{array}$ & $\begin{array}{l}\text { TP53 PEX4 C allele is } \\
\text { a risk factor for IVF } \\
\text { failure }\end{array}$ \\
\hline $\begin{array}{l}\text { Kang et al., } \\
2009\end{array}$ & $\begin{array}{l}\text { Study: } 272 \text { women with } \\
\text { unexplained infertility } \\
\text { Control: } 1071 \text { Women } \\
\text { recruited into the WISE } \\
\text { study }\end{array}$ & USA & $\begin{array}{l}\text { IVF: } 44.5 \%(121 / 272) \\
\text { Control: } \\
61 \% \\
(653 / 1071)\end{array}$ & $\begin{array}{l}\text { IVF: } 44.8 \% \\
\text { (122/272) } \\
\text { Control: } \\
33.3 \%(357 / 1071)\end{array}$ & $\begin{array}{l}\text { IVF: } 10.7 \% \\
\text { (29/272) } \\
\text { Control: } \\
5.7 \% \\
(61 / 1071)\end{array}$ & $\begin{array}{l}p 53 \text { allele encoding } \\
\text { Proline at codon } 72 \\
\text { was significantly } \\
\text { enriched over arginine } \\
\text { at codon } 72 \text { in IVF } \\
\text { patients }\end{array}$ \\
\hline $\begin{array}{l}\text { Patounakis } \\
\text { et al., } 2008\end{array}$ & $\begin{array}{l}\text { Study: Genotype and allele } \\
\text { frequencies of } 1056 \text { female } \\
\text { patients undergoing first } \\
\text { fresh non donor IVF cycle } \\
\text { and for } 2 \text { subsequent IVF } \\
\text { cycles if no implantation } \\
\text { occurred }\end{array}$ & USA & $\begin{array}{l}\text { IVF cycle } 1: 45 \% \\
\text { (476/1056) } \\
\text { IVF cycle } 2: 46 \% \\
\text { (132/289) } \\
\text { IVF cycle } 3: 51 \% \\
(37 / 72)\end{array}$ & $\begin{array}{l}\text { IVF cycle } 1: 44 \% \\
\text { (463/1056) } \\
\text { IVF cycle } 2: 45 \% \\
\text { (129/289) } \\
\text { IVF cycle } 3: 40 \% \\
(29 / 72)\end{array}$ & $\begin{array}{l}\text { IVF cycle } 1: 11 \% \\
\text { (117/1056) } \\
\text { IVF cycle } 2: 10 \% \\
\text { (28/289) } \\
\text { IVF cycle } 3: 8 \% \\
(6 / 72)\end{array}$ & $\begin{array}{l}\text { No significant } \\
\text { difference in genotype } \\
\text { or allele frequencies }\end{array}$ \\
\hline $\begin{array}{l}\text { Ghorbian et } \\
\text { al., } 2019\end{array}$ & $\begin{array}{l}\text { Study: } 100 \text { patients with } \\
\text { IVF failure } \\
\text { Control: } 100 \text { patients with a } \\
\text { natural pregnancy }\end{array}$ & Iran & $\begin{array}{l}\text { Study: } 10 \%(10 / 100) \\
\text { Control: } \\
47 \% \\
(47 / 100)\end{array}$ & $\begin{array}{l}\text { Study: } 72 \% \\
(72 / 100) \\
\text { Control: } \\
50 \% \\
(50 / 100)\end{array}$ & $\begin{array}{l}\text { Study: } 2 \% \\
(2 / 100) \\
\text { Control: } \\
3 \% \\
(3 / 100)\end{array}$ & $\begin{array}{l}\text { No significant } \\
\text { difference in genotype } \\
\text { or allele frequencies }\end{array}$ \\
\hline $\begin{array}{l}\text { Chan et al., } \\
2016\end{array}$ & $\begin{array}{l}\text { Study: } 1450 \text { IVF patients } \\
\text { Control: } 250 \text { fertile women }\end{array}$ & China & $\begin{array}{l}\text { Study: } 24.9 \% \\
(362 / 1450) \\
\text { Control: } 26 \% \\
(65 / 250)\end{array}$ & $\begin{array}{l}\text { Study: } 51 \% \\
(747 / 1450) \\
\text { Control: } 53.2 \% \\
(133 / 250)\end{array}$ & $\begin{array}{l}\text { Study: } 23.5 \% \\
(341 / 1450) \\
\text { Control: } 20.8 \% \\
(52 / 250)\end{array}$ & $\begin{array}{l}\text { The } \mathrm{C} \text { allele is a } \\
\text { protective factor in } \\
\text { IVF outcome }\end{array}$ \\
\hline $\begin{array}{l}\text { Baruffi et } \\
\text { al., } 2014\end{array}$ & $\begin{array}{l}\text { Study: } 390 \text { couples } \\
\text { subjected to IVF/ICSI }\end{array}$ & Brazil & $\begin{array}{l}\text { Study group: } 49 \% \\
(192 / 390) \\
\text { Implantation rate: } \\
19.6 \%\end{array}$ & $\begin{array}{l}\text { Study group: } 43.6 \% \\
(170 / 390) \\
\text { Implantation rate: } \\
18.6 \%\end{array}$ & $\begin{array}{l}\text { Study group: } \\
7.2 \%(28 / 390) \\
\text { Implantation rate: } \\
13.9 \%\end{array}$ & $\begin{array}{l}\text { No correlation with } \\
\text { clinical outcomes after } \\
\text { IVF/ICSI }\end{array}$ \\
\hline $\begin{array}{l}\text { Allanfan et } \\
\text { al., } 2015\end{array}$ & $\begin{array}{l}\text { Study: Group 1: } 20 \text { women } \\
\text { (no pregnancy after } 2 \\
\text { cycles of IVF) Control: } 40 \\
\text { women successfully } \\
\text { pregnant after IVF }\end{array}$ & Iran & $\begin{array}{l}\text { Group 1: } 75 \%(15 / 20) \\
\text { Control: } 92.5 \% \\
(37 / 40)\end{array}$ & $\begin{array}{l}\text { Group 1: } 25 \%(5 / 20) \\
\text { Control: } 7.5 \% \\
(3 / 40)\end{array}$ & None & $\begin{array}{l}\text { No association with } \\
\text { RIF }\end{array}$ \\
\hline
\end{tabular}

\section{References}

[1] ASRM: The practice committee of American Society of Reproductive Medicine. Definitions of infertility and recurrent pregnancy loss: a committee opinion. Fertility and Sterility. 2013; 99 (1): 63.

[2] Pandey MK, Rani R, Agrawal S. An update in recurrent spontaneous abortion. Arch Gynecol Obstet, 2005, 272 (2): 95-108.
[3] Coughlan C, Ledger W, Wang Q, Liu F, Demirol A, Gurgan T et al. Recurrent implantation failure: definition and management. Reproductive BioMedicine Online. 2014; 28 (1): 14-38.

[4] Polanski L, Baumgarten M, Quenby S, Brosens J, Campbell B, Raine-Fenning N. What exactly do we mean by 'recurrent implantation failure'? A systematic review and opinion. Reproductive BioMedicine Online. 2014; 28 (4): 409-423.

[5] Coulam C, Clark D, Beer A, Kutteh W, Silver R, Kwak J et al. Current Clinical Options for Diagnosis and Treatment of Recurrent Spontaneous Abortion. American Journal of Reproductive Immunology. 1997; 38 (2): 57-74. 
[6] Daher S, Mattar R, Gueuvoghlanian-Silva B, Torloni M. Genetic Polymorphisms and Recurrent Spontaneous Abortions: An Overview of Current Knowledge. American Journal of Reproductive Immunology. 2012; 67 (4): 341-347.

[7] Li TC, Makris M, Tomsu M, Tuckerman E, Laird S. Recurrent miscarriage: aetiology, management and prognosis. Hum Reprod Update 2002; 8: 463-81.

[8] Choi H, Choi B, Lee S, Kim J, Cha K, Baek K. Expression of angiogenesis- and apoptosis-related genes in chorionic villi derived from recurrent pregnancy loss patients. Molecular Reproduction and Development. 2003; 66 (1): 24-31.

[9] Kolte A, Nielsen H, Moltke I, Degn B, Pedersen B, Sunde L et al. A genome-wide scan in affected sibling pairs with idiopathic recurrent miscarriage suggests genetic linkage. MHR: Basic science of reproductive medicine. 2011; 17 (6): 379-385.

[10] Hu W, Feng Z, Atwal GS, Levine AJ. P53: a new player in reproduction. Cell Cycle. 2008 Apr 1; 7 (7): 848-52.

[11] Tang W, Zhou X, Chan Y, Wu X, Luo Y. p53 codon 72 polymorphism and recurrent pregnancy loss: a meta-analysis. Journal of Assisted Reproduction and Genetics. 2011; 28 (10): 965-969.

[12] Pflaum J, Schlosser S, Muller M. p53 Family and Cellular Stress Responses in Cancer. Frontiers in Oncology. 2014 Oct 21; 4: 285.

[13] Su M, Lin S, Chen Y. Genetic association studies of angiogenesis- and vasoconstriction-related genes in women with recurrent pregnancy loss: a systematic review and meta-analysis. Human Reproduction Update. 2011; 17 (6): 803-812.

[14] Kang H, Feng Z, Sun Y, Atwal G, Murphy M, Rebbeck T et al. Single-nucleotide polymorphisms in the p53 pathway regulate fertility in humans. Proceedings of the National Academy of Sciences. 2009; 106 (24): 9761-9766.

[15] Sakamuro D, Sabbatini P, White E, Prendergast G. The polyproline region of p53 is required to activate apoptosis but not growth arrest. Oncogene. 1997; 15 (8): 887-898.

[16] Feng Z, Zhang C, Kang H, Sun Y, Wang H, Naqvi A et al. Regulation of female reproduction by $\mathrm{p} 53$ and its family members. The FASEB Journal. 2011; 25 (7): 2245-2255.

[17] Pim D, Banks L. p53 polymorphic variants at codon 72 exert different effects on cell cycle progression. International Journal of Cancer. 2003; 108 (2): 196-199.

[18] Firouzibadi RD, Nasrin G, Maryam Ayazi R, Nasim T. Association of $\mathrm{p} 53$ polymorphism with ICSI/IVF failure and recurrent pregnancy loss. Australian and New Zealand Journal of Obstetrics and Gynaecology. 2009; 49 (2): 216-219.

[19] Pietrowski D, Bettendorf H, Riener E, Keck C, Hefler L, Huber $\mathrm{J}$ et al. Recurrent pregnancy failure is associated with a polymorphism in the p53 tumour suppressor gene. Human Reproduction. 2005; 20 (4): 848-851.

[20] Lledo B, Turienzo A, Ortiz J, Morales R, Ten J, Llácer J et al. Negative effect of P72 polymorphism on p53 gene in IVF outcome in patients with repeated implantation failure and pregnancy loss. Journal of Assisted Reproduction and Genetics. 2013; 31 (2): 169-172.
[21] Yoon S, Choi Y, Kim J, Hong M, Lee S, Yang K et al. No association of p53 codon 72 polymorphism with idiopathic recurrent pregnancy loss in Korean population. European Journal of Obstetrics \& Gynecology and Reproductive Biology. 2015; 192: 6-9.

[22] Fraga L, Dutra C, Boquett J, Vianna F, Gonçalves R, Paskulin $\mathrm{D}$ et al. p53 signaling pathway polymorphisms associated to recurrent pregnancy loss. Molecular Biology Reports. 2014; 41 (3): 1871-1877. $\rightarrow$ done.

[23] Kaare M, Butzow R, Ulander VM, Kaaia R, Aittomaki K, Painter JN. Study of p53 gene mutations and placental expression in recurrent miscarriage cases. Repod Biomed Online. 2009 Mar; 18 (3): 430-5. DOI: 10.1016/s1472-6483(10)60105-8.

[24] Coulam CB, Kay C, Jeyendran RS. Role of p53 codon 72 polymorphism in recurrent pregnancy loss. Reprod Biomed $\begin{array}{llll}\text { Online. } 2006 \text { Mar; } 12 & \text { (3): 378-82. DOI: }\end{array}$ 10.1016/s1472-6483(10)61013-9.

[25] Oliveira JB, Vagnini L, Petersen CG, Mauri AL, Baruffi, Franco Jr JG. Is there an association between the TP53 codon 72 polymorphism genotype and recurrent miscarriage? Fertility and Sterility. 2013 Sept; 100 (3): S192-S193.

[26] Franco Jr JG., Vagnini LD., Petersen CG., Mauri AL., Baruffi RLR., Oliveria JBA. Association of Single Nucleotide Polymorphisms with Recurrent Miscarriage. Fertility and Sterility. 2013. October: 100 (3): P550.

[27] Kay, C., Jeyendran, R. and Coulam, C., 2006. p53 tumour suppressor gene polymorphism is associated with recurrent implantation failure. Reproductive BioMedicine Online, 13 (4), pp. 492-496. DOI: 10.1016/s1472-6483(10)60635-9.

[28] Goodman, C., Jeyendran, R. and Coulam, C., 2009. P53 tumor suppressor factor, plasminogen activator inhibitor, and vascular endothelial growth factor gene polymorphisms and recurrent implantation failure. Fertility and Sterility, 92 (2), pp. 494-498. DOI: 10.1016/j.fertnstert.2008.07.022.

[29] Vagnini LD., Petersen CG., Mauri AL., Oliveira JB., Baruffi RLR., Franco Jr JG. A Prospective Evaluation of The Effect of Single Nucleotide Polymorphisms (SNPs) of Genes Involved In Human Reproduction on Recurrent Implantation Failure. Fertility and Sterility. 2013. October: 100 (3): P492.

[30] Allanfan S., Nazarabadi MH., Enghelabifar M., Kayatzadeh J., Abdai KS., Jalali M., Moradi F., Musaviar N., Reza JZ., Mojarrad M. No Association Between Recurrent Implantation Failure Following In Vitro Fertilisation with Gene Polymorphism P53. Iranian Journal of Obstetrics, Gynaecology and Infertility. 18 (172) (pp 18-25), 2015.

[31] Paskulin, D., Cunha-Filho, J., Souza, C., Bortolini, M., Hainaut, P. and Ashton-Prolla, P., 2012. TP53 PIN3 and PEX4 polymorphisms and infertility associated with endometriosis or with post-in vitro fertilization implantation failure. Cell Death \& Disease, 3 (9), pp. e392-e392. DOI: $10.1038 /$ cddis. 2012.116

[32] Patounakis, G., Treff, N., Tao, X., Lonczak, A., Scott, R. and Frattarelli, J., 2009. The p53 codon 72 single nucleotide polymorphism lacks a significant effect on implantation rate in fresh in vitro fertilization cycles: an analysis of 1,056 patients. Fertility and Sterility, 92 (4), pp. 1290-1296. DOI: 10.1016/j.fertnstert.2008.07.1783. 
[33] Ghorbian S., Mohammad Zadeh M., Nori M. Association between P53 PEX4 Polymorphism and IVF Outcome. European Journal of Human Genetics (2019) 26: 820-1023. https://doi.org/10.1038/s41431-018-0248-6.

[34] Chan, Y., Zhu, B., Jiang, H., Zhang, J., Luo, Y. and Tang, W., 2016. Influence of TP53 Codon 72 Polymorphism Alone or in Combination with HDM2 SNP309 on Human Infertility and IVF Outcome. PLOS ONE, 11 (11), p. e0167147. DOI: 10.1371/journal.pone.0167147.

[35] Baruffi RLR, Petersen CG, Vagnini LD, Renzi A, Oliveira-Pelegrin GR, Mauri AL, Massaro FC, Cavagna M, Oliveira JBA, Franco Jr, JG. The tp53 codon 72 polymorphism (RS1042522) in women is not associated with pregnancy outcomes after ART. Fertility and Sterility. 2014 Sept; 102 (3 SUPPL. 1): e233.

[36] Su, M., Lin, S. and Chen, Y., 2011. Genetic association studies of angiogenesis- and vasoconstriction-related genes in women with recurrent pregnancy loss: a systematic review and meta-analysis. Human Reproduction Update, 17 (6), pp. 803-812. DOI: $10.1093 /$ humupd/dmr027.

[37] Chen H, Yang X, Wang Z. Association between P53 Arg72Pro polymorphism and recurrent pregnancy loss: an updated systematic review and meta-analysis. Reprod Biomed Online. 2015 Aug; 31 (2): 149-53.
[38] Zhang Y, Wu YY, Qiao FY, Zeng WJ. Association between P53 polymorphism at codon 72 and recurrent spontaneous abortion. J Huazhong Univ Sci Technolog Med Sci. 2016 Jun; 36 (3): 402-5.

[39] Shi X., Xie X., Jia Y., Li S.. Maternal genetic polymorphisms and unexplained recurrent miscarriage: a systematic review and meta-analysis. Clin Genet 2017: 91: 265-284.

[40] Wiwanitkit V. Null effect of p53 codon 72 polymorphism on recurrent pregnancy loss and recurrent implantation failure: A summative assessment. Indian J Hum Genet. 2011 Sep-Dec; 17 (3): 248-249.

[41] Feng Y, Wu YY, Lin XJ, Yang L, Luo ZJ, Zhou YH, Chen J, Li $\mathrm{N}$, Lin Z, Zhao X. Associations between the codon 72 polymorphism of the TP53 gene and the risk of recurrent implantation failure. J Obstet Gynaecol Res. 2016 Feb; 42 (2): $184-9$.

[42] Smeenk L, Lohrum M. Behind the scenes: unravelling the molecular mechanisms of p53 target gene selectivity (Review). Int J Oncol 2010: 37 (5): 1061-1070.

[43] Dumont P, Leu JI, Della Pietra AC III, George DL, Murphy M. The codon 72 polymorphic variants of p53 have markedly different apoptotic potential. Nat Genet 2003; 33: 357-365.

[44] Hu W, Zheng T, Wang J. Regulation of Fertility by p53 Family Members. Genes Cancer. 2011 Apr; 2 (4): 420-430. 